\title{
SUCKLING PERIOD AND MILK PRODUCTIVITY OF THE SHEEP FROM BULGARIAN DAIRY SYNTHETIC POPULATION
}

\author{
Nevyana Stancheva ${ }^{1 *}$, Jivko Krastanov ${ }^{2}$, Teodora Angelova ${ }^{2}$, Georgi Kalaydzhiev², \\ Daniela Yordanova ${ }^{2}$ \\ ${ }^{1}$ Agricultural Institute, 9700 Shumen, Bulgaria \\ ${ }^{2}$ Agricultural Institute, 6000 Stara Zagora, Bulgaria \\ nevqna_68@abv.bg
}

\begin{abstract}
A b s t r a c t: The aim of the study was to determine the influence of suckling period on milk production of sheep from Bulgarian Dairy Synthetic Population (BDSP) grown in the Experimental base of the Agricultural Institute in Shumen. Total 5023 record are analyzed for milk yield for monthly control days of 601 ewes (born 2007th - 2012th years) produced from 1 to 6 lactations. To achieve unbiased evaluation was used animal model for test day. The statistical analysis included the following factors: month of the controls, consecutive lactation, age in days to the date of the control day, days suckling period and the number of lambs for the relevant lactation of the animal. The results show that the duration of the suckling period influences the milk productivity of sheep from BDSP. In ewes with suckling period of lambs exceeding 30 days, production of milk progressively decreases from 0.911 liters to 0.554 liters $(-0.357)$ at suckling period of $80-90$ days. Improving the management of the flock towards reducing the suckling period can lead to a significant increase in milk production.
\end{abstract}

Key words: sheep; Bulgarian Dairy Synthetic Population; milk productivity; suckling period; test-day model

\section{ДОЈНИОТ ПЕРИОД И ПРОИЗВОДСТВОТО НА МЛЕКО НА ОВЦИ ОД БУГАРСКАТА МЛЕЧНА СИНТЕТСКА ПОПУЛАЦИЈА}

\begin{abstract}
А п с т р а к т: Целта на студијава беше да се утврди влијанието на периодот на доење врз производството на млеко кај овци од бугарската млечна синтетска популација (BDSP), одгледувани во Експерименталната база на Земјоделскиот институт во Шумен. Вкупно се анализирани 5023 податоци за принос на млеко за месечните контролни денови од 601 овца (родени 2007 - 2012 година), продуктивни од 1 до 6 лактации. За да се постигне непристрасна евалуација, се користеше животински модел за тест-ден. Статистичката анализа ги опфаќа следните фактори: месец на контроли, последователна лактација, возраст во денови до датумот на контролниот ден, период на доење и бројот на јагниња за соодветната лактација на животното. Резултатите покажуваат дека времетраењето на периодот на доењето влијае на продуктивноста на млекото кај овците од BDSP. Кај овците со период на доење на јагниња над 30 дена производството на млеко постепено се намалува од 0.911 литри до 0.554 литри $(-0,357)$ во период на доење од 80 до 90 дена. Подобрувањето на управувањето со стадото во насока на намалување на периодот на доење може да доведе до значително зголемување на производството на млеко.
\end{abstract}

Клучни зборови: овци; бугарска млечна синтетска популација, продуктивност на млеко, период на доење; модел тест-ден

\section{INTRODUCTION}

In Bulgaria, sheep in the milk sector account for $70-75 \%$ of the total number of sheep and the most widely represented is Bulgarian Dairy Synthetic Population, registered in 2005. The main idea of its creation is production of sheep milk through a large massif of animals, suitable for intensive industrial use, with high milk productivity. The developed crossbreeding schemes involving East Friesian and Awassi breeds and the formation of the new milk population are described in detail by a number of authors (Boikovski, 1982; Boikovski et al., 2005, 2006; Dimitrov, 1986; Dimov, 1995; Hinkovski et al. 1979, 1984; Ivanova et al., 2013; Stancheva, 2003; Stancheva et al., 2015, 2016; Tzvetanov, 1989; Vitkov, 1987). Through the purposeful breeding activity of the scientific teams, nucleus flocks have been created, where the main selection criteria is high milk productivity and fertility. In 1992 the 
number of sheep in the newly created milk population reaches 548 320. The subsequent economic reform and the transfer to private ownership resulted to the eradication of a large part of the nucleus flocks and violation of the built-in population structure. In the desire to increase milk production, new farmers began to steadily cross their flocks with other, mostly foreign, dairy breeds. This process has led to substantial scientifically unjustified phenotypic and genetic variation, a different level of productivity, as the animals from this population are subject to constant criticism. Since 2007, selection in the private sector has been conducted by four non-governmental breeding organizations, whose activity has so far not developed to the desired direction - stabilization and determination of one type within the population, improvement through appropriate breeding methods, accurate productivity control and periodic analysis of the achieved results. In the available sources of information there is a lack of official data on the achieved level of milk productivity from the conducted controls.

Typical and consolidated flocks of BDSP are grown in several scientific units from the system of the Agricultural Academy (Institute of Agriculture - Shumen, Institute of Agricultural Sciences - Kostinbrod, Agricultural Institute - Stara Zagora and Institute of Agriculture - Karnobat). The results of the conducted researches show that in recent years the average milk productivity for a standardized 120days-period varies widely (76-133 liters) and does not meet the genetic capabilities of the animals for milk productivity in the range of 150 to 200 liters (Boikovski et al., 2006; Hinkovski et al., 2008; Ivanova and Raicheva, 2008; Ivanova, 2013; Ivanova et al., 2013; Raicheva and Ivanova, 2010, 2011a,b; Slavova et al., 2015; Stancheva and Staikova, 2013; Stancheva et al., 2006, 2014a,b). According to the same authors, the realization of genetic potential depends mainly on the provided nutrition of the animals and the environment conditions.

The sheep of Bulgarian Dairy Synthetic Population and other Bulgarian dairy breeds are mainly grown in semi-intensive and extensive production system, largely in the private sector. The average suckling period is within 60-65 days, which limits the amount of milk yield (Hinkovski et al., 2008; Ivanova, 2013; Zhelyazkova et al., 2014). In dairy sheep breeding, the reduction of the suckling period is a widespread practice and is a good opportunity to prolong the milking period and the quantity of milk obtained for sale (Ivanova et al., 2015; Mavrovska-Stoicheva, 2015; Pulina et al., 2007; Simeonov et al., 2012; Thomas et al., 2001).
The aim of the present study is to determine the impact of the suckling period on milk production in sheep of Bulgarian Dairy Synthetic Population, grown in the Experimental farm of the Agricultural Institute in Shumen.

\section{MATERIAL AND METHODS}

The subject of the present study are ewes from the Bulgarian Dairy Synthetic Population (born in the period 2007 - 2012) from the nucleus flock of the Experimental farm of the Agricultural Institute - Shumen. As the main selection trait is milk yield, only ewes registered for it are involved in this research. The flock is created by a modified scheme, as the genealogical structure is formed and built in at the stage of the crossing (Stancheva, 2003; Stancheva et al., 2014b, 2015, 2016). For more than 30 years, "intra-linear breeding" has been carried out with own-produced rams using a homogeneous selection coupled with temperate inbreeding. Animals are grown in stall-pasture at semi-intensive scheme. The reproductive process is standard, it takes place once a year in June-July. The sheep are artificially inseminated on an individual breeding plan at the age of 18 months after the flock have been formed. The lambing campaign runs from the second half of November to the end of December. Milking is mechanized and the duration of the milking period is about $150-180$ days. The suckling period range is from 55 to 60 days, with the tendency for the past few years to be reduced to $40-45$ days.

\section{Milk productivity and suckling period}

The total number of Test day records of milk yield is 5023. The study includes 4895 records of control days for daily milk yield of the ewes with established origin, producing 1 to 6 lactations. The control day milking data is derived from the monthly controls performed during the milking period (30-monthly controls for the 2009-2014 period) using the AC method specified in the ICAR nomenclature. To determine the impact of the suckling period on milk productivity, the ewes are grouped in 8 classes, at a range of 10 days ( $<20$ days, 21 to 30 , 31 to 40,41 to 50,51 to 60,61 to 70 , from 71 to 80 and $>80$ days suckling period).

To establish unbiased assessments of the variance, we base the analyses of the conducted studies on the following theoretical expectation: 
Milk productivity for various suckling periods is influenced by the genetic variation caused by the genealogy of the female and male population part, the effect of the animal, the age, the lactation sequence, the month and year of control, the number of lambs born for the respective lambing and the permanent mean effect.

In the used Testday model each daily milk control was considered as a separate observation.

To achieve the above solutions a mixed linear model is used as the statistic equations are as follows:

where:

$$
\mathbf{y}=X \mathbf{b}+Z \mathbf{u}+\mathbf{e}
$$

$\mathbf{y}$ - vector of milk yield observation in milliliters for the respective control day of each individual involved in the analysis;

b - vector of fixed effects - days of suckling period (main fixed effect -8 classes), year-month for each control, consecutive lactation, number of lambs in the liter of the respective lambing, year of birth of the animal, regression effect of age in days to the date of the control day;

$\mathbf{u}$ - vector of the random effects - effect of the animal with expectation for evaluation of the variation from the additive genetic effect, permanent mean effect;

e - random effect of unobserved factors;

$X$ and $Z$ - corresponding matrices of the variables described.

To achieve the above solutions are used software products VCE by Kovac et al. (2008), PEST by Groeneveld et al. (2002).

\section{RESULTS AND DISCUSSION}

The methods used to assess the signs of milk productivity of sheep in Bulgaria are based on their phenotypic values and do not reflect the environment and other non-genetic effects. The reported average daily milk yield for the flock in our research, is 0.945 liters at the first and 0.952 liters at the second lactation for 200 days lactation (Stancheva, 2003 ) and 0.881 liters at the first and 0.866 liters at the second and more lactations at a standard 120day period (Boikovski et al., 2006). In another study about the relation between body condition and milk yield for sheep produced in 2011-2012, Stancheva and Staikova (2013) reported an average daily milk yield of $0.899-0.934$ liters (BCS 3-3.5 and above 3.5 on the first lactation) and $0.848-0.911$ liters (BCS 3-3.5 and above 3.5 on the second and more lactations). For sheep of the same population, the reported average daily milk yield at the various lactations in the flock of the Institute of Agricultural Sciences - Kostinbrod, varies from 0.793 to 0.971 liters (Hinkovski et al., 2008) and 0.843 to 0.997 liters in the flock of the Agricultural Institute - Stara Zagora (Slavova et al., 2015). Contemporary genetic evaluation of the traits of milk production is based on the individual recordings on the day of the performed controls - a model of the control (test) day (Bauer et al., 2012; Gutierrez et al., 2007; Horstick, 2001; Ligda et al., 2002; Oravcová et al., 2005, 2006; Othmane et al., 2002; Serrano et al., 2001), due to the possibility of taking account of the environment effects (sequential lambing, age of the first lambing, litter size, number of lambed or weaned lambs, suckling period, stage of lactation, etc.) related to lactation.

Average value for the trait testday milk yield TDY for the period of the survey is 0.896 liters \pm 0.34 at a high coeficient of variation $(\mathrm{CV}=38 \%)$. The big differences between the minimum $(0.297$ liters) and maximum (3.143 liters) daily milk yield indicate an opportunity to increase the genetic potential of the animals by refining the breeding activity and managing the production system on the farm. Confirmation of our opinion is found in the established assesments of milk production of sheep in dependence on the year of birth (Figure 1). There is a variation observed, which makes it impossible to formulate a certain trend in changing the trait level. The animals born in 2011 are with a positive deviation and the highest estimate $(+0.058$ and 0.954 liters) followed by those born in $2007(+0.025$ and 0.921 liters) and 2010 ( +0.015 and 0.911 liters).

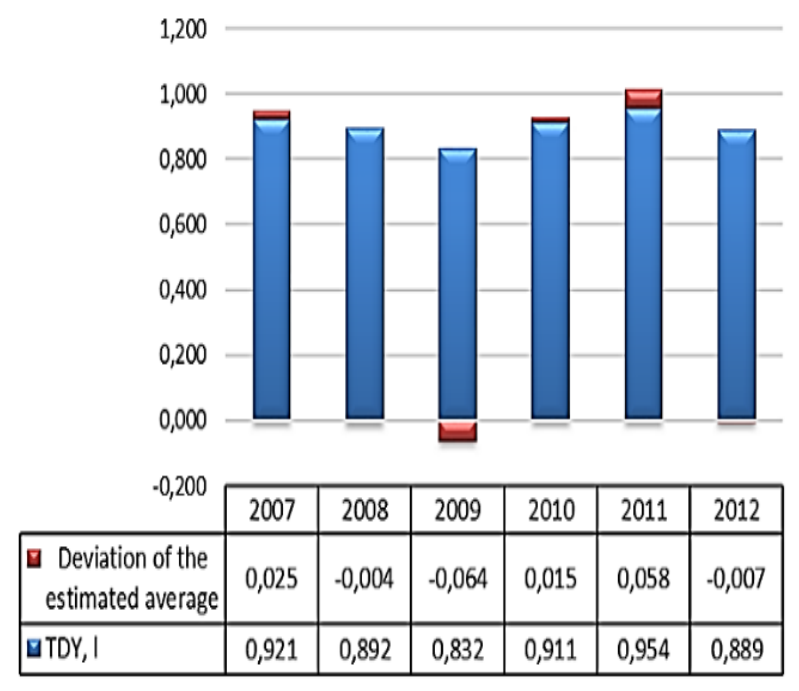

Fig. 1. Estimates of the milk yeld affected by the year of birth 
With slight negative deviations are the estimates for sheep born in 2008 and $2011(-0.004$ and -0.007 liters), with the lowest estimate and a highest negative deviation from the average for the population are those born in 2009 (0.832 and -0.064 liters).

It is known that the milk production of sheep is bred and an individual trait and is influenced by a number of factors such as age, month of lambing, sequential and duration of lactation, fertility, nutrition, breeding strategies, management of production systems, year of birth and production, disease resistance and others (Alkass and Akreyi, 2016; Carta et al., 2009; Dikmen et al., 2007; Djabirski et al., 2006; Jawasreh and Khasawneh, 2007; Oravcová et al., 2006; Pacinovski et al., 2012, 2016; Pulina et al., 2007).

Estimates of realized milk productivity in the year of production of the ewe generally decline (Figure 2). The highest milk yield has sheep's in 2009 (0.991 liters) when the animals lambed in 2007 are lactating. The lowest milk production has been reported in 2012 ( 0.677 liters), with a negative deviation from the total average ( -0.219 liters). In our opinion, these results do not reflect the genetic endowments of the animals, but rather they are due to different numbers of lactating sheep, unbalanced ration, skips in the breeding technology and non-genetic interactions. A credible effect of the year of production is established by Zhelyazkova et al., (2014) in sheep of SPBM grown in two private flocks, Jawasreh and Khasawneh, (2007) for Awassi sheep breed grow in Jordan and theirs crosses in Macedonia (Pacinovski et al., 2016).

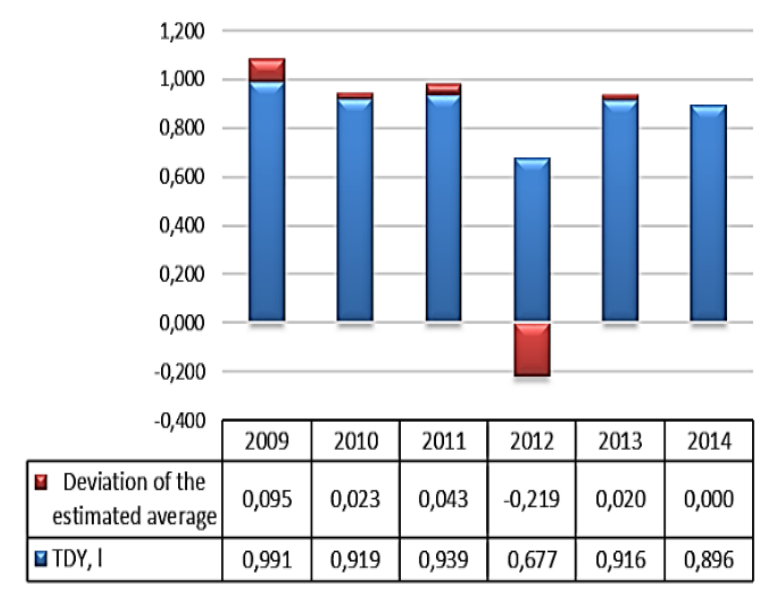

Fig. 2. Estimates of the milk yeld affected by the year of prodction

The results obtained by us for the average daily milk yield on the day of the controls are higher than the values reported for the Awassi breed 0.796 liters (Jawasreh and Khasawneh, 2007), Tsigai and Improved Valachian -0.620 and 0.630 liters (Oravcova et al. 2005), Istrian Pramenka - 0.708 liters (Komprej et al., 2003), Black-Faced and Blond-Faced Latxa -0.820 and 0.740 liters (Gabina et al., 1993). Significantly higher is the average daily milk yield of specialized breeds for milk East Friesian - 2.330 liters (Hamann et al., 2004); Assaf - 1.930 liters (Pollot and Gootwine, 2004), Lacaune - 1.640 liters (Barillet et al., 2001; Berger, 2004).

By comparing the milk yield of sheep from Synthetic Population with those foreign breeds with high milk yield, it is necessary to take into account the existing differences both in productive systems and the length of the standard milking period (180 days - Assaf and 150 days for East Friesian and Lacaune breeds) and the suckling period ( 0 days for Assaf, 30 days for Lacaune and East Friesian breeds).

Our results show that the duration of the suckling period has a significant impact on the milk yield of the sheep (Figure 3). The highest yield have the ewes with a suckling lamb for a period of up to 20 (0.962 liters) and 30 days (0.911 liters). According to existing practice on the farm, during this period, is made the first examination of the lambs, breeding lambs are marked out and the rest of the lambs are for sale. A small part of the ewes whose lambs are subject to various scientific experiments and those with non-living or dead lambs are also in these two classes.

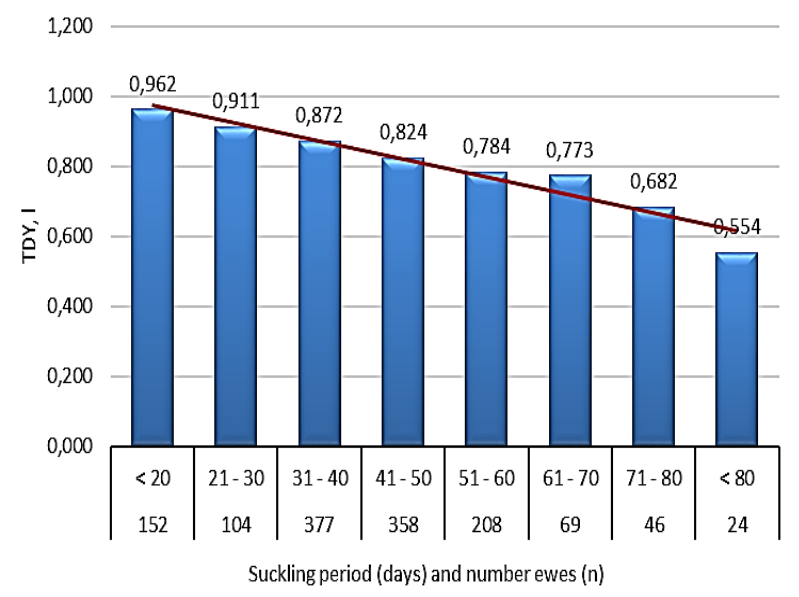

Fig. 3. Milk yeld according to the duration of suckling period

The largest numbers of ewes are with a suckling period of lambs of up to 40 and 50 days (736 ewes) with a milking rate of 0.872 liters for the first 
and 0.824 liters for the second ones. It is then weaned part of the lambs for breeding and the rest of the lambs are sale for breeding for other flocks or for slaughter. Lower and with close values is these trait for the sheep from the following two classes 0.784 liters $(51-60$ days) and 0.773 liters $(61-70$ days), and the lowest milk yield have the animals with a period of $71-80$ and above 80 days $(0.682$ and 0.554 liters). The human factor (shepherd) has a major role for forming these classes because of the long-established belief that lambs left for replace of the flock should be suckled for longer.

The obtained results show that the reduction of the suckling period is an important reserve for increasing the quantity of milk and improving the economic profitability of the flock. In this direction, it is necessary to look for opportunities for appropriate methods of early weaning and feeding the lambs in order not to reduce the amount of milk production after weaning (Pulina et al., 2007; McKusick et al., 1999; 2001). For ewes from the East Friesian breed, Thomas et al., (2001) reported that accustom the lambs suckling milk replaces and begin milking the ewes until 24-36 hours after lambing increase milk yield by $61 \%$ compare to machine milking after weaning lambs at 30 days of age. In our country, Simeonov et al., (2012) found that early weaning at 19-20 days of age at an average live weight of 9.815 $\mathrm{kg}$ instead of the traditional 60 days of age of lambs from Pleven Black Headed breed, allowed an additional $47.3 \mathrm{~kg}$ of milk from one ewe. For sheep of the same breed, Mavrovska-Stoycheva (2015) reported that in the early weaning of lambs and beginning of the milking period of sheep, 30 days after lambing, in the first month are obtained 41.7 liters of additional milk from sheep.

\section{CONCLUSIONS}

The established significant differences in the minimum (0.297 liters) and maximum (3.143 liters) of milk yield on the day of the controls show an opportunity to increase the genetic potential of the sheep by refining the breeding activity and creating optimal conditions for the realization of the genetic potentialities possessed by the animals.

In ewes with a suckling period over 30 days, milk yield on control day (TDY) progressively decreased from 0.911 to 0.554 liters ( -0.357 liters) for ewes with suckling period over 80 days. Improving the management of the flock to reduce the period of suckling period can lead to a significant increase in milk productivity.
Acknowledge: This study became possible thanks to Project G 113 "Analysis of genetic variability in sheep populations breeding in Bulgaria" of the Agricultural Academy.

\section{REFERENCES}

[1] Alkass, E. J. and Akreyi, I. A. I.: Milk Production of Awassi and Karadi ewes Raised Under Farm Conditions, $A d$ vanced Journal of Agricultural Research Vol. 4 (01), pp. 008-013 (January, 2016).

[2] Barillet, F., Marie, C., Jacquin, M., Lagriffoul, G., Astruc, J. M.: The French Lacaune dairy sheep breed: use in France and abroad in the last 40 years. Livest. Prod. Sci., 71, 1729 (2001).

[3] Bauer, J., Milerski, M., Přibyl, J., Vostrý, L.: Estimation of genetic parameters and evaluation of test-day milk production in sheep. Czech J. Anim. Sci., 57 (11), 522-528 (2012).

[4] Berger, Y. M.: Breeds of sheep for commercial milk production. In: Proceedings of 10th Great Lake Dairy Sheep Symposium. Hudson, Wisconsin. University of Wisconsin, Madison, 2004, pp.14-20.

[5] Boikovski, St.: Results of an absorbing crossbreeding of Black-Head Plevenska and fine-fleece North-East Bulgarian, Shumen type, ewes with Avasi rams. I. Productivity of F1 crossbreds, Animal Science XIX (5), 12-17 (1982) (Bg).

[6] Boikovski, St., Stancheva, N., Stefanova, G.: The Newly Created Milk Sheep Breed, "Eyro-Klima", Shoumen, 2005, pp. 222, (Bg).

[7] Boikovski, St., Stefanova, G., Stancheva, N.: Milk yield for milking period in the sheep from the Newly Created Milk Breed in Bulgaria, Bulgarian Journal of Agricultural Science, 12, 1, 145-152 (2006).

[8] Carta, A., Casu, S., Salaris, S.: Current state of genetic improvement in dairy sheep, Journal of Dairy Science, Vol. 92, No. 12, 5814-5833 (2009).

[9] Dikmen, S., Turkmen, I., Ustuner, H., Alpay, F., Balci, F., Petek, M., Ogen, M.: Effect of weaning system on lamb growth and commercial milk production of Awassi dairy sheep. Czech Journal of Animal Science, 52 (3), 70-76 (2007).

[10] Dimitrov, Em.: Creation of milk sheep breeding in Sofia District. PhD Thesis, Sofia, 1986, 164 p., ( Bg).

[11] Dimov, D.: Results of the study on applied breeding schemes for creating dairy sheep. PhD Thesis, Sofia, 1995, 145 $\mathrm{p},(\mathrm{Bg})$.

[12] Djabirski, V., Pacinovski, N., Dimov, G., Eftimova, E., Palaševski, B.: Effect of parity, season and test day on daily productivity of East Friesian ewes in Macedonia, Journal of Mountain Agriculture on the Balkans, vol. 9, 1, 54-67 (2006).

[13] Gabina, D., Arrese, F., Arranz, J., Beltran de Heredia I.: Average milk yields and environmental effects on Latxa sheep. J. Dairy Sci., 76, 1191-1198 (1993).

[14] Groeneveld, E., Kovac, M., Wang, T.: PEST - 32 MB, VERSIONS 4.2.3, Multivariate Prediction and Estimation, CYGWIN_98-4.101.3.2<0.39-3-2>, Department of Animal Sciences, University of Illinois, 2002.

[15] Guti'Errez, J. .P., Legaz, E., Goyache, F.: Genetic parameters affecting 180-days standardised milk yield, test-day 
milk yield and lactation length in Spanish Assaf (Assaf. E) dairy sheep, Small Ruminant Research, 70, 233-238 (2007).

[16] Hamann, H., Horstick, A., Wessels, A., Distl, O.: Estimation of genetic parameters for test day milk production, somatic cell score and litter size at birth in East Friesian ewes. Livestock Production Science, 87 (2-3), 153-160 (2004).

[17] Hinkovski, Tz., Donchev, P., Dochevski, D.: Diary sheep breeding and sheep management technologies, Zemizdat, Sofia, 1979, 213 p., (Bg).

[18] Hinkovski, Tz., Stoyanov, A., Donchev, P. Boikovski, S.: Methodical instructions for creation of synthetic sheep population and technologies of raisin. Agric. Academy, Sofia, 1984, 37 p., (Bg).

[19] Hinkovski, Tz., Raicheva, E., Metodiev, N.: Estimation of productivity of ewes from the Bulgarian Dairy Synthetic Population. Animal Science, № 3, 35-41 (2008) (Bg).

[20] Horstick, A.: Genetic analysis of milk performance and linear type traits in East Friesian and Black and Brown milk sheep. Dissertation. Tierärztlich Hochschule, Hannover, 2001

[21] Ivanova, S., Ivanova, T., Angelov, L., Raicheva, E.: Milk yield, physicochemical properties and fatty acid composition of milk from sheep of the Synthetic Population Bulgarian Dairy Breed, Journal of Animal Science, 2, 15-24 (2015) (Bg).

[22] Ivanova, T., Raicheva, E.: Assessment the effect of some factors on lactation. Conference "80 Years Agrarian Sciences in the Rhodopes", Proceedings , 2008, pp. 67-71, (Bg)

[23] Ivanova, T.: Milk production of ewes from Synthetic Population Bulgarian Milk in the flock of IAS - Kostinbrod. $\mathrm{Ph}$ D Thesis, Kostinbrod, 2013, 139 p. (Bg).

[24] Ivanova, T., Metodiev, N., Raicheva, E.: Effect of the genealogic line on the ewes from Synthetic Population Bulgarian Milk, Bulgarian Journal of Agricultural Science, 19, 1, 158-162 (2013).

[25] Jawasreh, K. I. Z. and Khasawneh, A. Z.: Genetic evaluation of milk production traits in Awassi sheep in Jordan. Egyptian J. of Sheep and Goat Sciences, Vol. 2 (2), 83100. (2007).

[26] Komprej, A., Gorjanc, G., Malovrh, Š., Kompan, D., Kovač, M.: Test day model and genetic parameters in Slovenian dairy sheep. In: Proceedings of the 54th Annual Meeting of the EAAP, Rome, Italy. 2003, pp. 351.

[27] Kovac, M., Groeneveld, E., Garcia-Cortez, A.: VCE - 6, Version 6.0.2, MS-Windows, Windows-x86_32-gfor, 2008.

[28] Ligda, Ch., Gabriilidis, G., Georgoudis, A.: Estimates of genetic parameters for test day somatic cell counts in Chios dairy sheep. In: Proceedings of the Seventh World Congress on Genetics Appl. to Livest. Prod., Montpellier, France, CD-ROM Communication No. 09-21, 2002.

[29] Mavrovska-Stoycheva, I.: Influence of grazing and preserved forage on milk production of sheep, $\mathrm{PhD}$ Thesis, Pleven, 2015, 148 p., (Bg)

[30] Mckusick, B. C., Berger, Y. M. , Thomas, D. L.: Effects of three weaning and rearing systems on commercial milk production and lamb growth. Proceedings of the 5 th Great Lakes, Dairy Sheep Symposium. November 4-6, 1999, Bratteboro, Vermont, USA, pp. 16-32.

[31] Mckusick, B. C., Thomas, D. L., Berger, Y. M.: Effect of weaning system on commercial milk production and lamb growth of East Friesian Dairy sheep. Journal of Dairy Science, 84, 1660-1668. (2001).

[32] Oravcová, M., Groeneveld, E., Kovač, M., Peškovičová, D., Margetín, M.: Estimation of genetic and environmental parameters of milk production traits in Slovak purebred sheep using test day model. Small Rumin. Res. 56, 113120 (2005)

[33] Oravcová, M., Margetín, M., Peškovičová, D., Daňo, J., Milerski, M., Hetényi, L., Polák, P.: Factors affecting milk yield and ewe's lactation curves estimated with test-day models. Czech J. Anim. Sci. 51, 483-490 (2006).

[34] Othmane, H., Carriedo, J. A., San Primitivo, F., De La Fuente, L. F.: Genetic parameters for lactation traits of milking ewes: protein content and composition, fat, somatic cells and individual laboratory cheese yield. Genet. Sel. E 34, 581-596 (2002).

[35] Pacinovski, N., Cilev, G., Eftimova, E., Pacinovski, A.: Influence of non-genetic factors on the annual milk production of Ovchepolian Sheep in the Republic of Macedonia. Krmiva, 54, 4, 115-122 (2012).

[36] Pacinovski, N., Dzabirski, V., Porcu, K., Cilev, G., Joshevska, E., Petrovic, M. P., Antunovic, Zv.: Factors influencing productive traits of Awassi crossbreeds in Macedonia, Biotechnology in Animal Husbandry 32 (2), 145-161 (2016).

[37] Pollotm, G. E., Gootwine, E.: Reproductive performance and milk production of Assaf sheep in an intensive management system. J. Dairy Sci., 87, 3690-3703 (2004).

[38] Giuseppe Pulina, Anna Nudda, Nicolò Pietro Paolo Macciotta, Gianni Battacone, Salvatore Pier Giacomo Rassu, Antonello Cannas: Non-nutritional factors affecting lactation persistency in dairy ewes: A review, Italian Journal of Animal Science, 6, 2, 115-141 (2007).

[39] Raicheva, E., Ivanova, T.: Duration of lactation and milk production in ewes from synthetic population Bulgarian milk depending on the order of lactation. Animal Science, Supplement 1, 58-63 (2010) (Bg).

[40] Raicheva, E., Ivanova, T.: A previous study on the some parameters connecting whit the milk production at early conceived as ewe lambs from Synthetic Population Bulgarian Milk. Journal of Mountain Agriculture on the Balkans, 4, 656-666 (2011 $)(\mathrm{Bg})$.

[41] Raicheva, E., Ivanova, T.: Effect of the age at conceiving on the productivity traits at dairy sheep in Bulgaria. Biotechnology in Animal Husbandry, Vol. 27, № 3, Book 2, 1147-1156 (2011 $)$.

[42] Serrano, M., Ugarte, E., Jurado, J. J., Pérez-Guzmán, M. D., Legarra, A.: Test day models and genetic parameters in Latxa and Manchega dairy ewes. Livest. Prod. Sci. 67, 253-264 (2001).

[43] Simeonov, M., Todorov, N., Kirilov, A., Stoicheva, I.: Comparison of different methods for early weaning of lambs, Journal of Animal Science, 6, 14-25 (2012) (Bg).

[44] Slavova, P., Laleva, S., Popova, Y.: Studying the variation of productive traits milk yield and fertility of dairy sheep from Bulgarian Synthetic Population as a result of conducted selection, Journal of Animal Science, 3, 20-25 (2015) (Bg).

[45] Stancheva, N.: Phenotypic and Genotypic Parameters of selection indices in the newly created milk sheep population in Bulgaria. PhD Thesis, Sofia, 2003, 188 pp. (Bg). 
[46] Stancheva, N., Boikovski, S. T., Stefanova, G., Dimitrov, D., Rusenov, A.: Regularities in lactation persistency of lactation and possibilities for using part of lactation in tribal work in ewes from Synthetic Population Bulgarian Milk. International Scientific Conference - Stara Zagora, June 1-2, 2006, Vol. 2. Vet. Medicine, Animal Studies. 244-247, 2006 (Bg).

[47] Stancheva, N., Staikova, G.: Body condition score and productive performance of the Synthetic Population Bulgarian Milk Sheep. J. Animal Science, Supplement 6, pp. 42-46 (2013) (Bg).

[48] Stancheva, N., Dimitrova, I., Georgieva, S.: Biological fertility and milk yield in Bulgarian Dairy Synthetic Population sheep according to breeding line, Agricultural Science and Technology, Vol. 6, No 1, pp $17-20$ (2014 $)$.

[49] Stancheva, N., Raicheva, E., Laleva, S., Ivanova, T., Iliev, M., Kalaydhziev, G.: Present status, problems and development of the Synthetic Population Bulgarian Milk sheep from the herds of Agricultural Accademy, Journal of Animal Science, 6, 3-11 (2014b) (Bg).

[50] Stancheva, N., Dimitrova, I., Georgieva, S.: Growth and development of sheep from Synthetic Population Bulgarian Milk. $2^{\text {nd }}$ International Symposium for Agriculture and Food, 7-9 October 2015,Ohrid, Republic of
Macedonia - Symposium Proceedings, 2015, pp. 29-35, ISBN 978-9989-845-63-5.

[51] Stancheva, N., Krastanov, J., Angelova, T., Kalaydhziev, G., Yordanova, D., Laleva, S.: Genetic structure of the sheep from the Bulgarian Dairy Synthetic Population on the Experimental Farm of Agricultural Institute - Shumen, Macedonian Journal of Animal Science, Vol. 6, No. 1, pp 17-24 (2016).

[52] Thomas, D. L., Berger, Y. M., Mckusick, B. C.: Effects of breed, management system and nutrition in milk yield and milk composition of dairy sheep. Journal of Animal Science, 79, E16-E20 (2001).

[53] Tzvetanov, V.: Study on effect of breed in the early stages of creating a synthetic population of sheep milk. PhD Thesis, Sofia, 1989, p.153 (Bg).

[54] Vitkov, V.: Zootechnical characteristic of the productivity of milk Sheep from Blackhead Pleven Breed and its crosses with the breeds Eastern Friesian and Awasi on equal and changing level of feeding. PhD Thesis, Sofia, 1987, $153 \mathrm{p}$. (Bg).

[55] Zhelyazkova, P., Karailanska, L., Panayotov, At., Dimov, D.: Study on milk yield of Syntetic Population Dairy Sheep around Plovdiv Region of Bulgaria, Journal of Animal Science, 1-2, 22-29 (2014) (Bg). 
